University of Nebraska - Lincoln

DigitalCommons@University of Nebraska - Lincoln

Faculty Publications - Department of

Philosophy

Philosophy, Department of

3-18-2013

\title{
Reconciliation or Reconstruction? Further Thoughts on Political Forgiveness
}

Jean Axelrad Cahan

University of Nebraska-Lincoln, jcahan1@unl.edu

Follow this and additional works at: https://digitalcommons.unl.edu/philosfacpub

Part of the Philosophy Commons

Cahan, Jean Axelrad, "Reconciliation or Reconstruction? Further Thoughts on Political Forgiveness" (2013). Faculty Publications - Department of Philosophy. 65.

https://digitalcommons.unl.edu/philosfacpub/65

This Article is brought to you for free and open access by the Philosophy, Department of at DigitalCommons@University of Nebraska - Lincoln. It has been accepted for inclusion in Faculty Publications Department of Philosophy by an authorized administrator of DigitalCommons@University of Nebraska - Lincoln. 


\title{
Reconciliation or Reconstruction? Further Thoughts on Political Forgiveness
}

\author{
Jean Axelrad Cahan \\ University of Nebraska-Lincoln
}

Over the past decade a substantial literature has emerged on the concept of political forgiveness and the process of restorative justice. This article argues that importing an idea of forgiveness into political affairs is a mistake. It is not necessary for the promotion of peace and security, and it is has been construed in a way that leans heavily toward Christian conceptions of forgiveness, as is evident in the influence of Desmond Tutu. The article also examines the influence of Hegelian recognition theory in current discussions of the political benefits of forgiveness, and reviews the case of postwar German-Jewish relations, which conformed more closely to traditional Jewish thinking on forgiveness than to the Christian-Hegelian (multicultural) model.

Polity (2013) 45, 174-197. doi:10.1057/pol.2013.5; published online 18 March 2013

Keywords forgiveness; reconciliation; restorative justice; German-Jewish relations; truth commissions; Hegel

The dead are nourished by judgement.-Elias Canetti

We can live together, we just can't sleep.

- Resident of the former Yugoslavia

In recent years a substantial literature has emerged on the aftermath of conflict and transitional justice. The period since the end of World War Two is often characterized as one of growing commitment to restorative justice, as opposed to the "victors' justice" of earlier times. Restorative justice underscores the usefulness of a variety of gestures and policies which include truth commissions, statements of apology, restitution efforts of various kinds, and reparations payments as means of furthering reconciliation. It emphasizes recognition of wrongdoing, as well as of the full equality of the victims.

Several theorists of restorative justice have sought to define a concept of political forgiveness. Some are interested in a secular version; others seek to revive or import a religious notion, especially a Christian one. ${ }^{1}$ In these discussions the case of German-Jewish reconciliation after the Second World 
War frequently arises. Thus Roy Brooks, a legal scholar concerned with reparations for slavery, writes:

. . . Adenauer's contrition captures the essence of the post-Holocaust spirit of heightened morality, victim-perpetrator identity, egalitarianism, and restorative justice. It is a model, a moral blueprint, of how governments today, including the government of the United States, should respond to redress claims. Indeed, the United Nations regards Germany's redress program, which also provided funds for the new state of Israel, as 'the most comprehensive and systematic precedent of reparations by a Government to groups of victims for redress of wrongs suffered. ${ }^{2}$

The theorist Elazar Barkan, who has explored a wide range of cases, also treats the German-Jewish case as a model:

The idea of compensation, the rhetoric of guilt, and limited recognitionforgiveness were translated, through the legal medium of restitution, into new possibilities in international relations. ${ }^{3}$

Perhaps the most important text on this topic is No Future Without Forgiveness, ${ }^{4}$ in which Desmund Tutu explicitly takes issue with Jewish ideas and actions in the aftermath of the Second World War and with the status of Palestine. He also expresses the hope that Jewish scholars will respond with analyses of their own.

Amid the trend toward restorative justice, the German-Jewish case continues to resonate. However, the gradual establishment of reparations payments and of diplomatic relations between the Federal Republic of Germany and the State of Israel too often is discussed in the light of notions of reconciliation and political

1. Frequently cited works relating to the topic of forgiveness in politics include: Elazar Barkan, The Guilt of Nations: Restitution and Negotiating Historical Injustice (New York: W.W. Norton \& Company, 2000); Elazar Barkan and Alexander Karn, ed., Taking Wrongs Seriously: Apologies and Reconciliation (Palo Alto: Stanford University Press, 2006); Ian Buruma, The Wages of Guilt: Memories of War in Germany and Japan (New York: Farrar Straus Giroux, 1994); Roy Brooks, Atonement and Forgiveness: A New Model for Black Reparations (Berkeley: University of California Press, 2004); Jon Elster, Closing the Books: Transitional Justice in Historical Perspective (Cambridge: Cambridge University Press, 2004); Amitai Etzioni and David E. Carney, eds., Repentance: A Comparative Perspective (Lanham, MD: Rowman \& Littlefield Publishers, Inc., 1997); Priscilla B. Hayner, Unspeakable Truths: Confronting State Terror and Atrocity (New York: Routledge, 2001); Avishai Margalit, The Ethics of Memory (Cambridge: Harvard University Press, 2002); Martha Minow, Between Vengeance and Forgiveness: Facing History After Genocide and Mass Violence (Boston: Beacon Press, 1998). A useful overview of some of the literature may also be found in Will Kymlicka and Bashir Bashir, ed., The Politics of Reconciliation in Multicultural Societies (Oxford: Oxford University Press, 2008).

2. Brooks, Atonement, xv.

3. Barkan, Guilt of Nations, xxiii.

4. Desmond Mpilo Tutu, No Future Without Forgiveness (New York: Doubleday, 1997). 
forgiveness that have been imported retroactively either from the South African case or as a result of broad aspirations for multicultural harmony. Such discussions have therefore tended to distort what occurred during the German-Jewish rapprochement and the policy inferences that might be drawn from it.

In this article I argue that in the paradigm case of German-Jewish relations after the Second World War, recognition of the moral wrong done to Jews, to Jewish identity, and to Jewish memory and the processes of apology, forgiveness, and reconciliation either were not present at all, or were at best secondary for all parties involved in the negotiations over reparations and restitution. I cannot analyze other cases here because of space constraints. Still, I believe that they also show that economic and power-political considerations are primary in the "reconciliation" process. Indeed, a strong case could be made that this happened in Tutu's South Africa.

I hold, further, that what occurred in the German-Jewish case was not reconciliation predicated on forgiveness. It was a process of constructing conditions for basic security. The goal of social and political reconstruction differs from that of forgiveness and reconciliation, though the former may provide a basis for the latter. Nonetheless, working toward reconstruction-economically, socially and politically-should not be viewed as only a mundane and materialistic affair. The aim of reconstruction is to put in place a "minimally decent society." This is valuable in itself, even though it is quite different from seeking to re-create (through apologies, truth commissions, and other processes thought to facilitate forgiveness), a society in which everyone can behave as though nothing had happened.

In my view, the choice to forgive should be left to the individual and her "comprehensive view" of morality. Forgiveness is not a value chosen or a decision taken on one's behalf by the state or a representative of the state. It remains outside the sphere of the political, and no special concept of "political forgiveness" is desirable. Thus, even though I shall suggest that a Jewish conception of forgiveness would be more applicable to postwar German-Jewish relations than some others, it is preferable to avoid the term "forgiveness" altogether in the political sphere.

\section{Approaches to Forgiveness in Politics}

Although the Holocaust in many ways has become a paradigm case, analyses of forgiveness have not included a Jewish religious perspective. Indeed, there is

5. Stuart Hampshire cited in Rajeev Bhargava, "Restoring Decency to Barbaric Societies," in Truth v. Justice: The Morality of Truth Commissions, ed. Robert I. Rotberg and Dennis Thompson (Princeton, NJ: Princeton University Press, 2000), 45-46. 
some disagreement as to whether forgiveness has or requires a religious basis of any kind.

One of the most frequently cited views on forgiveness is that of Hannah Arendt. Her status as both German-Jewish refugee and distinguished political philosopher has given her paradoxical pronouncement on forgiveness an unusual measure of authority. Arendt's secular outlook, which sought to acknowledge the seemingly transcendent enormity of the crimes perpetrated, was encapsulated in her declaration that "we are unable to forgive what we cannot punish and we are unable to punish what has turned out to be unforgiveable." Mary Dietz has argued that Arendt's principal concern both in this formulation and in her broad theoretical investigations of the Holocaust was to "construct a way back from the abyss" so that Jews could give up their "fanatical hatred" and so that Germans could rid themselves "of the complicity imposed by the Nazis." By conceptualizing political space anew and providing a new "dream," Arendt, like Thucydides, sought to "block the human impulse to ruminate upon and incessantly rekindle the perpetual memory of hardship and evil, thereby fanning the flames of desire for retribution and revenge." 6

Apart from the absence of evidence to support the notion that there was widespread desire for revenge among Jews anywhere, the noteworthy point about Arendt's view-or Dietz's interpretation of it-is that it was among the earliest to see forgiveness as a humanly constructed, step-by-step procedure or process which could be enacted for the larger political purpose of achieving peace. More recently, similar views may be found in the work of P.E. Digeser, who argues for a view of forgiveness along the lines of debt forgiveness in commerce. That is, after some suitable procedure of acknowledgment of wrongdoing and efforts to make restitution on the part of the debtor, the creditor or victim will move toward re-establishing friendly relations or reconciliation. Legal or civic authorities would specify the procedure to be followed. ${ }^{7}$ Donald Shriver has proposed a similar method. ${ }^{8}$ This contrasts to some extent with other views, especially religious ones, which emphasize the instantaneous, even gratuitous, character of forgiveness, either divine or human. In this way of thinking, forgiveness, though it may require apology and atonement in some form, is ultimately a matter of "grace," an inexplicable, uncalculating emotional movement toward the perpetrator, who has not necessarily made an effort to seek forgiveness.

6. Mary Dietz, "Arendt and the Holocaust," in The Cambridge Companion to Hannah Arendt, ed. Dana Villa (Cambridge: Cambridge University Press, 2000), 92.

7. P. E. Digeser, Political Forgiveness (Ithaca: Cornell University Press, 2001), passim.

8. Donald W. Shriver, Jr., An Ethic for Enemies: Forgiveness in Politics (New York: Oxford University Press, 1995). 
As we shall see in the next section, the view of forgiveness as a method to obtain peace is more or less that of Desmond Tutu, as well as the Jewish thinker Vladimir Jankelevitch. ${ }^{9}$ Other conceptions, including Jewish religious ones, tend to emphasize the repentance which should take place before forgiveness, not only on an individual level but in public life. The legal theorist Jeffrie Murphy, in a volume on civic repentance organized by the communitarian thinker Amitai Etzioni, writes:

We simply do not value repentance the way we once did; and the world has suffered a loss thereby. [It is] seen as a vestigial relic of a religious world view to which most people pay only lip service. Or they do not see its relevance to crime and punishment defined around secular values. ${ }^{10}$

I agree that in secular accounts of political forgiveness, repentance has been largely reduced to formal governmental apology. Such apologies by national leaders may be helpful in post-conflict or post-trauma reconciliation; but it is difficult to determine whether such apologies express broad and deep processes of repentance and forgiveness within a society more generally.

\section{Influence of Christian Thought and of Hegel}

The current aspiration to achieve social reconciliation through forgiveness and recognition of "the other," perhaps even to the point of vitiation of meaningful distinctions between victims and perpetrators, has, two sources: the Christian theology underlying the renowned South African Truth and Reconciliation Commission, and the Hegelian underpinnings of contemporary multicultural theory. Although Christianity is often mentioned as shaping the South African truth commission, one rarely sees discussion of Archbishop Tutu's own words and his possibly relevant comments on Jews and Judaism. I begin, however, with the Hegelian-philosophical aspect of this point, since its possible influence on thinking about political reconciliation has received even less attention. ${ }^{11}$

The nineteenth-century German Idealist philosopher G.W.F. Hegel placed great weight on the notion that individuals-whether particular human beings, whole societies, or even Absolute Being itself—can fully actualize themselves only if

9. Vladimir Jankelevitch. Forgiveness, trans. Andrew Kelley (Chicago: University of Chicago Press, 2005).

10. Jeffrie Murphy, "Repentance, Punishment and Mercy," in Repentance: A Comparative Perspective, ed. Amitai Etzioni and David E. Carney (Lanham, MD: Rowman \& Littlefield Publishers, 1997), 146.

11. Two important exceptions should be noted: the volume edited by Kymlicka and Bashir cited in note 1 above, and Michael Hardimon, Hegel's Social Philosophy: The Project of Reconciliation (Cambridge: Cambridge University Press, 1994). 
they are recognized by other individuals from whom they have become differentiated. ${ }^{12}$ Restitution processes represent, for a number of theorists, a step toward fulfillment of the need for recognition in the contemporary era:

A theory of conflict resolution based on restitution may illuminate the effort by many nations and minorities to gain partial recognition and overcome conflicting historical identities through construction of a shared past. ${ }^{13}$

The locus classicus of the phenomenon of recognition is Hegel's master-slave zdialectic in the Phenomenology of Spirit. But while contemporary multiculturalism and recognition theory look toward to a condition of full equality and liberal democracy, Hegel's version of the dialectic closes with the subsiding of one of the parties into awareness of his own finitude and a resulting acceptance of slavery over death, although initially he was supposed to be engaged in a struggle to the death. ${ }^{14}$ Hegel was interested not so much in the dynamic of recognition of otherness, as theorists of multiculturalism would have it, but in the nature of self-consciousness and the ability to see oneself in the other.

Other sections of the Phenomenology restate the relative unimportance (indeed, the unreality) of essential otherness. Hegel argues in a section on deceit that both individuality and action are intricate, indecipherable mixtures of good and bad; that action is in any case all good, because it is the self-expression of individuality; and that

[t]herefore feelings of exaltation, or lamentation, or repentance are altogether out of place. For all that sort of thing stems from a mind which imagines a content and an in-itself which are different from the original nature of the individual and the actual carrying out of it in the real world. ${ }^{15}$

Thus he sees the attitude of repentance as rather a waste of time because it is based on a misrecognition of the other, a false reflection created by the imagination of the repentant person.

In another section on forgiveness Hegel insists that one who receives a confession must, like the philosopher reflecting on good and bad, relinquish judgment. An initial, mutual refusing-to-yield stand-off between offender and victim must end, not in death, but in reconciliation.

12. Cf. Hardimon, Hegel's Social Philosophy; and Charles Taylor, Hegel (Cambridge: Cambridge University Press, 1975).

13. Barkan, Guilt, xli.

14. Cf. Patchen Markell, Bound By Recognition (Princeton: Princeton University Press, 2003).

15. G.W.F. Hegel, Phenomenology of Spirit, trans. A.V. Miller (Oxford: Clarendon Press, 1977), 242. 
The consciousness that judges in this way is itself base, because it divides up the action. . . Further, it is hypocrisy, because it passes off such judging, not as another manner of being wicked, but as the correct consciousness of the action, setting itself up in this unreality and conceit of knowing well and better above the deeds it discredits. . . By putting itself, then, in this way on a level with the doer on whom it passes judgement, it is recognized by the latter as the same as himself.

Perceiving this identity and giving utterance to it, he [whose action is being judged] confesses this to the other, and equally expects that the other. . will respond in words in which he will give utterance to this identity with him, and expects that this mutual recognition will now exist as a fact. His confession is not an abasement, a humiliation, a throwing away of himself in relation to the other. . . ${ }^{16}$

The recognition that takes place is not a recognition of otherness, but a sort of metaphysical solidarity. Each side discerns in the other the combination of universality and particularity, objectivity and subjectivity that is present in every action. That is, the offender/confessing person perceives his identity with the other not through feelings of guilt, shame, or repentance, but through something akin to sneering defiance. The evil consciousness confesses and expects in return a relinquishing of "the weapon" of judgment about good and evil, and a relinquishing of the "unreal" self of the judging person. Initially, the judging side-that is, the "beautiful soul" of the person receiving the confession-fails to see its unity with the other life, and refuses to give up its judgment. Eventually, however, this hard-heartedness is worn down in some fashion; the judge comes to see himself in the wicked other, and extends forgiveness.

The forgiveness which it extends to the other is the renunciation of self, of its unreal essential being. . . and acknowledges that what thought characterized as bad, viz. action,-is good; or rather it abandons this distinction of the specific thought and its subjectively determined judgement. . . ${ }^{17}$

From here, the two consciousnesses proceed to reconciliation, where no acts or individuals are divided by thought and judgment, and where the two parties are unified in the universality of reason or Absolute Spirit.

16. Ibid., 405

17. Ibid., 407-408. 
This process of reconciliation imposes no hardship, in Hegel's view, because individual memory disappears:

The wounds of the spirit heal and leave no scar behind. The deed [the crime] is not imperishable element; it is taken back by Spirit into itself, and the aspect of individuality in it. . .straightway vanishes. ${ }^{18}$

Perhaps on the level of a metaphysical self wounds leave no scars, but it is difficult to conceive how this could be the case after military, political, legal, and social battles (the very ones Hegel apparently regards as unreal). The need to receive acknowledgment of wrong (or the need to avoid admitting wrong); the need for judgment; and the return to a distinctive identity that has been violated or distorted through conflict-these seem to be ineradicable needs, not parts of identity that either victims or perpetrators would ever relinquish. These needs may have been the source of the problems surrounding President Reagan's visit to the German military cemetery at Bitburg in 1985. His visit and remarks there implied a commonality and universality of suffering that vitiated distinctions between the experiences and identities of victims and perpetrators under the National Socialist regime. Some restitution theorists may deny that forgiveness and reconciliation require forgetting or abandonment of judgment, but the conception of reconciliation laid out by Hegel does require it. ${ }^{19}$

Tutu's conception of forgiveness, like Hegel's, de-emphasizes differences between perpetrators and victims and stresses "our common humanity." ${ }^{20}$ Neither Hegel (who to some degree was committed to Lutheranism) nor Tutu acknowledges that a specifically Christian approach to forgiveness may not be universally applicable. In face of the objection, raised by the President of Rwanda among others, that certain atrocities are unforgivable, Tutu calls for universal harmony. He defines "forgiveness" as "abandoning your right to pay back the perpetrator in his own coin"-that is, as not seeking retribution in the sense of revenge. ${ }^{21}$ Forgiveness also means having empathy for the perpetrator; understanding what led him to act in the way that he did; and beginning the relationship anew. ${ }^{22}$ Ideological and practical differences will arise at the beginning of a new relationship. Those who see forgiveness-either on behalf of the dead (if that is possible) or on one's own account-as a form of social

18. Ibid., 407 .

19. My reading differs from that of Michael Hardimon, who argues that Hegelian reconciliation is not a return to a former condition as though nothing had happened. Cf. Hardimon, Hegel's Social Philosophy, 85.

20. Tutu, No Future, 120.

21. Ibid., 272.

22. Ibid 
amnesia or even a form of injustice will think and act differently from those who forgive in the way advocated by Archbishop Tutu.

Although Tutu and many other theorists insist that forgiving does not mean forgetting, others fear that forgiving not only will mean forgetting, but will induce a failure of recognition. After all, memories of historical wrongs constitute parts of a people's particular identity. They therefore are not prepared to commence behaving as though the former enemy had not acted at all. ${ }^{23}$

Moreover, Judaism as a religion, and not only as a culture or ethnicity, depends heavily on memory. God is remembered as the one who made possible the exodus of the Jews from slavery in Egypt. To set aside this belief about God (and the corresponding historical narrative) would require abandoning an essential feature of religious as well as cultural identity. The tight connection between memory and identity is true of not only Jews in ancient Egypt, but Jews in twentieth-century Europe, Native Americans, Africans of many kinds in the postcolonial era, and many other groups.

Tutu castigates the Jewish people for not sharing his vision of forgiveness and reconciliation:

It is a little difficult for me to understand how it is that Jews should be willing to accept the substantial compensation being paid out as reparation by European governments and institutions for complicity in the Holocaust. For if we accept the argument that they cannot forgive on behalf of those who suffered and died in the past, logic would seem to dictate that those who did not suffer directly as a result of the action for which the reparation is being paid should also be capable of receiving compensation on behalf of others. Their stance also means that there is still a massive obstacle to the resumption of more normal and amicable relationships between the community of the perpetrators and the community of those who were wronged. There will always be this albatross hanging around the neck of the erstwhile perpetrators, whatever they might want to do about acts of reparation and whatever new and better attitudes they might want to bring to the situation. ${ }^{24}$

"Their stance" (that is, the stance that of "the Jews") purportedly poses a "massive obstacle" to resumption of "more normal" relations, as Tutu conceives it. But, as will be explained below, the Jewish position has not precluded the resumption of constructive relations altogether. Nor, initially, did large numbers of Germans ("the erstwhile perpetrators") seek forgiveness or want to adopt new attitudes, 2000).

23. Cf. Robert Gibbs, Why Ethics? Signs of Responsibilities (Princeton: Princeton University Press,

24. Tutu, No Future, 277-78. 
though the German leadership did express that wish. Furthermore, reparation and restitution payments were not received on behalf of those who had died. They were received as compensation to survivors unable to work and to accumulate savings on account of their past "imprisonment" in death and concentration camps; as restitution, where possible, of identifiable property that was appropriated by the National Socialist regime for military and police purposes during the war; and as payments to the State of Israel to assist in the costs of large-scale immigration of survivors. Although the German government has paid billions in restitution, the amount that an individual survivor receives is frequently only a fraction of what is required to live (let alone of what he or she might have possessed if the Nazi persecution had not taken place).

\section{Jewish Conceptions of Forgiveness}

For the sake of completeness, let us inquire as to how forgiveness is understood in Jewish religious thought. There are many reasons to do so. If reconciliation processes and procedures are to be attempted (as they currently are), it seems self-evident that all participants should have some preliminary notion of how their opponents envision reconciliation, and of the extent that those conceptions have been shaped by religious and cultural traditions rather than by a more recent and somewhat artificially constructed secular or civic version. Participants should share some minimal understanding of which reconciliatory procedures are feasible if not welcome, and should be able to assess how far reconciliation efforts are actually likely to go.

For example, one concrete step that might have facilitated the reconciliation process in the German-Jewish case was an explicit and public apology from Chancellor Adenauer and his government. The Jewish/Israeli demand for such an apology was not a negotiating tactic. Nor was the demand for an apology a question of staying in a vengeful frame of mind or "nursing a grudge vicariously for those who cannot speak for themselves any longer." ${ }^{25}$ The demand was a derivation from the Jewish religious conception of how reconciliation may proceed. With greater knowledge of the Jewish idea of forgiveness, we will be able to see better that forgiveness was not required for the return of peaceful, stable relations between Germany and Israel.

By briefly surveying Jewish ideas about forgiveness, I do not mean to suggest that they should replace the Christian understanding or any other model of international and intra-societal reconciliation. I simply wish to note that the conduct of Israeli and other Jewish representatives in the aftermath of World War II comports more with traditional Jewish thought on forgiveness than with some putative ideal of universal

25. Ibid., 279. 
harmony. As an alternative to Tutu's version of forgiveness, the Israeli diplomats pursued peace yet did not regard the former perpetrator as though he had not acted.

Probably the best-known and most cohesive statement of the Jewish view of forgiveness is to be found in the Mishneh Torah, a codification produced in the twelfth century by the philosopher Maimonides. In the section "Laws of Repentance" (hilchot teshuvah), as elsewhere, Maimonides relied heavily on the Hebrew Bible and slightly less so on the Talmud, which remains a primary source. Several branches of Judaism-Reform, Conservative, and Orthodox (itself divided into a number of sub-groups)—share this view of repentance and forgiveness. The expositions of two prominent Jewish thinkers: Joseph Soloveitchik (Orthodox) and Elliott Dorff (Conservative) inform the following interpretation.

Jewish religious thought distinguishes two senses of forgiveness. ${ }^{26}$ One sense, seliha, is that of an ineffable form of purification, a spiritual return to God's presence. It is preceded by a type of repentance, taharah, which seeks to overcome the subjective sense of being mired in sin and to remove moral impurity. A second sense of forgiveness is that of mehila, which is pardon or acquittal, and a release from debt and further punishments or obligations. Mehila is preceded by repentance in the sense of kapparah, or performing acts of material or concrete reparation. Of paramount importance, however, is the explicit request for forgiveness from the offended party, whether divine or human (but one cannot ask for divine forgiveness if one has not first sought human forgiveness). The ability to make such a request is thought to follow from a turning of the spirit from the habits and actions that led to the offense, and a turning/returning both toward both a more just mode of behavior and, ideally, toward God. Such a turning is called teshuvah or "response" to God.

Certain procedures are to be followed when one human being seeks forgiveness from another. For example, the one who seeks forgiveness should ask the victim (directly) for forgiveness three times in the presence of others. A problem arises, of course, if the wrong committed is murder, or if the victim has died in some other way and is not in a position to receive the apology and request for forgiveness. The Talmud advises the wrongdoer to seek forgiveness over the grave of the victim and to say: "I have acted wrongly towards you" (Yoma 45c). For others who may have been affected by the offense or crime of murder, the question remains whether they can or should respond in a conciliatory way. ${ }^{27}$

26. Cf. Soloveitchik on Repentance: The Thought and Oral Discourses of Rabbi Joseph B. Soloveitchik, comp. Pinhas Peli (New York: Paulist Press, 1984); Elliott Dorff, To Do the Right and the Good: A Jewish Approach to Modern Social Ethics (Philadelphia: Jewish Publication Society, 2002). David Konstan has argued that historically neither Judaism nor Christianity had a definite conception of interpersonal forgiveness comparable to those found in the modern era. See his Before Forgiveness: The Origins of a Moral Idea (Cambridge, UK: Cambridge University Press, 2012).

27. I take this to be the question posed by Simon Wiesenthal's The Sunflower. 
The Jewish idea of mehila resembles what has recently, in discussions of reparations for African Americans, been termed the "tort model of redress." It also resembles those approaches which treat political forgiveness on analogy with debt repayment and forgiveness. ${ }^{28}$ The tort model, though including a demand for acknowledgment of wrongdoing and apology, primarily seeks rectification of injustice according to a relatively specific legal scheme of punishments and compensations. Forgiveness entails the acceptance of the proffered apology, together with material compensation, for the sake of social peace and stability. It does not include arriving at "purification" or reconciliation in some larger, more diffuse sense.

We might say, in accordance with the Jewish conception of repentance and forgiveness as I have presented it, that Germany has gone some distance in acquitting itself of its debt to Jews through its compensation payments, its denazification procedures, its new constitution, and other practical measures. And to this extent, the world community and perhaps the Jewish community as well have pardoned Germany. But forgiveness in the sense of seliha will likely never occur. We have no inkling of divine intention in this regard. On their own admission, many Germans who were involved in the killing directly or indirectly have not repented. ${ }^{29}$ The feeling that moral impurity lingers may account for the feeling among some that a permanent question mark hangs over German contributions to the international political community.

Jewish and Christian ideas relating to forgiveness and reconciliation differ in several respects. First, when the victim cannot respond because he is dead, Judaism leaves open the question of what surviving family members or the community should think about forgiveness and reconciliation, though on no account should revenge be sought. According to Tutu's view, survivors should proffer forgiveness in all cases, even when remorse has not been expressed and forgiveness not requested. ${ }^{30}$ In Judaism, an explicit request for forgiveness must be made before it can be considered. It is likely for this reason that Israeli negotiators insisted on a formal statement of remorse from the Germans before any further transactions could take place.

Second, the ultimate vision for humanity to which Christian ideas of forgiveness are supposed to contribute is quite different from Jewish ones. In Jewish thought, there is no unified conception of an end-state to which humanity

28. Cf. Brooks, Atonement; Digeser, Political Forgiveness.

29. Cf. Norbert Frei, Vergangenheitspolitik: Die Anfange der Bundesrepublik und die NS-Vergangenheit (Munchen: Deutscher Taschenbuch Verlag, 1999); Alexander Mitscherlich and Margarethe Mitscherlich, Die Unfahigkeit zu Trauern: Grundlagen des Kollektiven Verhaltens (Munich: R. Piper \& Co. Verlag, 1977); Hannah Arendt, "The Auschwitz Trial," in Hannah Arendt, Responsibility and Judgment, ed. Jerome Kohn (New York: Schocken Books, 2003).

30. Tutu, No Future, 272-73. 
is tending. Tutu, in contrast, anticipates an era when all differences between peoples disappear:

There is a movement, not easily discernible, at the heart of things to reverse the awful centrifugal force of alienation, brokenness, division, hostility and disharmony. God has set in motion a centripetal process, a moving toward the center, toward unity, harmony, goodness, peace and justice, a process that removes barriers. Jesus['s] . . .arms[are] thrown out to clasp all, everyone and everything, in a cosmic embrace, so that all, everyone, everything, belongs. None is an outsider, all are insiders, all belong. There are no aliens, all belong in one family, God's family, the human family. There is no longer Jew or Greek, male or female, slave or free. . . ${ }^{31}$

Jews and Greeks, though not without universalistic tendencies in their own thought, do not necessarily share this vision.

I now present a brief overview of postwar German-Jewish relations, which I believe illustrates the Jewish perspective in which the acceptance of material reparations is a form of debt repayment-that is, forgiveness in the sense of mehila-but does not entail the granting of forgiveness (in an emotional, spiritual, or purifying sense) on one's own behalf or on behalf of the dead.

\section{German-Jewish Relations After 1945}

I differ from those who hold that since World War II a progressive moral development has been at work in the resolution of conflicts. I maintain, instead, that internal stability and entry or reinstatement into the international community after conflict (and, in particular, after World War Two) were the results of political-economic pressures. There has been a subordination of memories of past injustices on the part of both victims and perpetrators of injustice who cannot afford to remain aloof from the system of international political economy. The perpetrators might also desire to rehabilitate the status of their ethnic group or country within the world community, to regain recognition of their group or country as a valued member of the international community, or to demonstrate that their society is morally reputable and responsible. But in the case of postwar Germany, these motives do not seem to have been as strong as the politico-economic ones. Conversely, economic and political considerations created a willingness on the part of Israel and worldwide Jewish communities to engage in direct negotiations with West Germany.

During the first two or three years after the establishment of both the State of Israel (1948) and the Federal Republic of Germany (1949), neither side contacted

31. Ibid., 265. 
the other. Mutual hatred was very high. Small groups of Jews here and there fantasized about revenge on a mass scale, but the vast majority was preoccupied with reconstructing their individual lives. Most Germans believed that the destruction of European Jewry was carried out by someone else-for example, by the regime without assistance from the public-and that Germans too had suffered enormously.

By the early 1950s it became clear that the economy of Israel was in dire straits. The country strained to absorb hundreds of thousands of refugees, experienced severe production and export shortfalls, and suffered a major balance of payments crisis. In addition, the state continually needed resources in its struggles with its Arab neighbors, who were increasingly supported by the Soviet bloc.

West Germany, meanwhile, had to deal with a devastated infrastructure, severe population losses, the management of millions of refugees from the East, and twenty-billion dollars in reparations payments to the Allies. Although these reparations obligations, decided upon at conferences in Potsdam, Yalta, and Paris, were not as crushing as those imposed at Versailles after the First World War, they still represented a hardship for the newly emerging West German state. The Marshall Plan kept West Germany afloat economically, but that arrangement was scheduled to end in 1952. It was in West Germany's interest, therefore, to display a cooperative attitude with the West during the numerous negotiations over its war debt and also over arrangements governing steel production, currency exchange rates, and occupation costs. West Germany may also have wished to rehabilitate its moral standing in the eyes of other Western powers, but this does not appear to have been uppermost in the minds of most government officials who were worried about the impact of restitution payments on Germany's already staggering economy, and who also were concerned about Arab reaction to German relations with Israel and, ultimately, about the prospects of German reunification. Restitution discussions took place only after Chancellor Adenauer and a handful of other government officials insisted that West Germany take financial, political, and moral responsibility for its crimes, and after pressure was exercised from representatives of Jewish organizations and Israel. ${ }^{32}$

32. The foregoing account is based on the following sources: Howard M. Sachar, A History of Israel from the Rise of Zionism to Our Time, 2nd ed. (New York: Alfred A. Knopf, 1996); George Lavy, Germany and Israel: Moral Debt and National Interest (London: Frank Cass, 1996); Tom Segev, The Seventh Million: The Israelis and the Holocaust, trans. Haim Watzman (New York: Hill and Wang, 1993); James Knowlton and Truell Cates, trans., Forever in the Shadow of Hitler? Original Documents of the Historikerstreit, the Controversy Concerning the Singularity of the Holocaust (New Jersey: Humanities Press, 1993); Michael Wolffsohn, Eternal Guilt? Forty Years of German-Jewish-Israeli Relations, trans. Douglas Bokovoy (New York: Columbia University Press, 1993); Nicholas Balabkins, West German Reparations to Israel (New Brunswick: Rutgers University Press, 1971); Inge Deutschkron, Bonn and Jerusalem: The Strange Coalition (Philadelphia: Chilton Book Company, 1970); Ronald Zweig, German Reparations and the Jewish World: A History of the Claims Conference (Boulder, CO: Westview Press, 1987). 
The Jewish people had not been included among the recipients of reparations worked out at Potsdam in 1945 or at any of the other conferences of the four major victorious powers. The only provision was for $\$ 25$ million in German assets in neutral countries to be used to cover the losses of Jewish victims who had died without heirs. Yet the European Jews were among those who had suffered most from the Nazi regime, in every way. At issue were three sets of claims: individual claims for restitution; Jewish institutional claims; and a collective claim on behalf of the Jewish people.

For nearly two years, Dr. Noah Barou, vice-president of the British section of the World Jewish Congress, patiently negotiated in private with West German officials. In March of 1950, the West German Foreign Ministry agreed in principle to collective indemnification. Because there were no official channels between Israel and West Germany, Israel made a claim for about $\$ 1.5$ billion through diplomatic notes to the Allies. The amount was based on estimates of the material losses of the European Jews and of the cost of supporting those Jews who had moved to Israel. Israel's figure was intended to be a starting point for negotiations. The Allies took the position that Israel as a sovereign state had to deal directly with the state of West Germany. The Soviet Union did not respond at all to the portion of the note that was relevant to East Germany.

Before negotiations could proceed, however, Israel insisted that Chancellor Adenauer, in the name of the German people, issue a statement acknowledging the wrongs done to the Jews. Adenauer, himself a devout Catholic, had no objections to this. Indeed, he felt a moral obligation to try to rectify both material and moral crimes. But large sections of the German government and population opposed the proposed action. It took three months for the two states to agree on a draft speech, which Adenauer finally delivered to the German parliament on 27 September 1951. In the speech, he acknowledged the unremitting shame that had been brought upon Germany and the need to educate citizens about antiSemitism. The speech, however, fell short of being an explicit admission of guilt. ${ }^{33}$

After the negotiations had become public, the discussion turned to the question of a permanent German diplomatic mission to Israel. According to an editorial in the Jerusalem Post:

From every practical and contemporary point of view official relations with Germany are necessary for the strengthening of the State. . . To sacrifice even a part of Israel's security and stability in order to reject Bonn's proposal indicates. . . a false estimate of the nature of diplomatic relations. ${ }^{34}$

33. Deutschkron, Bonn and Jerusalem, 37.

34. Lavy, Germany and Israel, 119. 
The contents of the editorial reflected profound disagreements within the Israeli government. Speaker of the Knesset Yosef Sprinzak, for example, refused to contemplate any relations with West Germany. He argued that "the honor of the Jewish people precludes any acceptance of restitution from Germany even if it were voluntarily and spontaneously offered." 35 Others agreed with Prime Minister Ben Gurion and Foreign Minister Sharett, who argued that the survival of Israel took priority over everything else and, furthermore, that there might be a moral obligation to seek and benefit from reparations payments:

All the sinister prophecies and scorn regarding the "naiveté" of the previous coalition Government have now been fully disproved. The country's entire economy in all its branches, regardless of class and party affiliations, is benefiting from these payments. What should be our overriding consideration in this case? To immerse ourselves in memories and sacrifice the present and the future to the past? Are not the survival of the State and the elevation of its stature supreme injunctions for Jewish survival and Jewish honor both present and future? ${ }^{36}$

During the negotiations, large street demonstrations took place, and Knesset deliberations threatened to spin completely out of control. One historian described this problem of reparations and negotiation with Germany as "perhaps the single gravest crisis of Israeli democracy." ${ }^{37}$

After much internal discussion in both governments and societies, recent memory was subordinated to the requirements of political economy. The documents concluding the negotiations among West Germany, Israel and the Jewish Claims Conference were signed on the same day and in the same building that Adenauer signed the document founding the European Coal and Steel Community: Luxemburg City Hall, 10 September 1952.

To recapitulate: the development of postwar German-Jewish relations was driven by problems of economic and political security rather than moral considerations. Not all scholars will agree with this thesis. Elazar Barkan, for instance, sees the German-Jewish reparations process as the first in a long line of negotiations and agreements that continue today. They constitute a new system of international morality alongside and often superseding power politics.

35. Sachar, History of Israel, 465.

36. Foreign Minister Moshe Sharett quoted in David Ben-Gurion, Israel: A Personal History, trans. Nechemia Myers and Uzy Nystar (New York: Funk \& Wagnalls, Inc., 1971), 442.

37. Sachar, History of Israel, 466. See also Ben-Gurion, Israel, 399. 
Although many Jews objected to whitewashing German guilt, those who prevailed eventually negotiated partial "forgiveness" for partial restitution. The outcome created a model for a new global morality. ${ }^{38}$

Having learned from experience, the Allies in 1945 did not impose reparations upon Germany. Instead the United States accepted the burden of rebuilding Europe and Japan and initiated the Marshall Plan. This introduced a novel factor into international relations: Rather than hold to a moral right to exploit enemy resources, as had been done previously, the victor underscored future reconciliation ... .

Within this context of nonvindictiveness the modern conception of restitution was born. ... While the Allies' Marshall Plan and their nonretributive stance toward Germany may have been imaginative politics, the innovative phenomenon in the German-Jewish agreement was that the perpetrator compensated the victims on its own volition in order to facilitate self-rehabilitation. ${ }^{39}$

Barkan, whose account is pervaded by the vocabulary of sin, repentance, and forgiveness, contends that Jews and Germans faced a Faustian dilemma when deciding whether to negotiate for material restitution. But from the Jewish and Israeli point of view, there was no question of forgiveness at all. The Germans understood this perfectly well and were not seeking forgiveness. ${ }^{40}$ Indeed, some say that later, when Chancellor Willy Brandt dropped to his knees during a visit to the former Warsaw Ghetto, he was quite aware that his request for forgiveness would not be granted by descendants of the victims and that the gesture was deeply unpopular in West Germany. ${ }^{41}$

The two governments hoped to secure and enhance their own economic and political positions. They wanted to increase possibilities for economic and political development through relations with each other and with other nations. In the case of Israel, the government needed immediate economic and financial aid for the absorption of immigrants from Europe as well as from Arab countries, and for the running of the state. The material advantages for West Germany were more long-term and complex. In addition to the economic issues tied to occupation costs, currency-exchange rates, and steel production, West Germany was interested in gaining a foothold in the power politics of the Middle East,

38. Barkan, Guilt, 26.

39. Ibid., xxiii (emphasis added).

40. Ben-Gurion, Israel, passim.

41. Raymond Cohen, "Apology and Reconciliation in International Relations," in From Conflict Resolution to Reconciliation, ed. Yaacov Bar Siman-Tov (New York: Oxford University Press, 2004), 187. 
where the former Allies were pursuing Saudi oil and were worried about Egyptian nationalism and new circumstances in Iran, Turkey, and Yemen. ${ }^{42}$

The Soviet Union's support for the United Nations' plan to partition Palestine and form the State of Israel proved to be momentary. Even though significant numbers of Eastern European immigrants to Palestine were imbued with socialist ideals, this was not enough to align Israel firmly on the Soviet side. This became even truer because of the anti-Semitism evident in the arrest and show trials of numerous Eastern European (Czech, Hungarian and Bulgarian) government officials of Jewish origin.

Both the Federal Republic and Israel wanted to be aligned with the Western power bloc, economically and politically. For Germany, this required suppression of any lingering resentment over military defeat as well as the elimination of any remnants of Nazi ideology and practice. It also required appearing to respond adequately to the Israeli/Jewish request for restitution and reparations. Israel needed to repress its immeasurable grief and anger for the sake national survival.

Nothing resembling collective repentance took place in Germany after the war. To say that reconciliation in some sort of philosophico-moral sense, let alone forgiveness with its religious connotations, was involved is simply wrong. Barkan's thesis-that the Federal Republic and Israel voluntarily entered the compensation agreement and that it therefore was a new form of restitution-is true only in a limited sense. Restitution and reparations took place within the context imposed by the four major allies in 1945, and that context had its requirements. Furthermore, evidence suggests that actual material restitution began locally, in the four zones of occupied Germany. The first instance took place in the Russian sector. Similar actions then occurred in the American sector. In both cases, the military forces occupying the zone exerted pressure. ${ }^{43}$ I do not see how one could claim that the German-Jewish restitution agreement was based more on moral considerations than on power politics.

\section{Implications for Other Cases}

What emerged out of the German-Jewish negotiations was something less than a new system of international morality based on recognition of identity, forgiveness, and reconciliation. The scale of the German material reparations effort may have been unprecedented, but so was the scale of the conflict. These efforts at material reparation, again, were not initially complemented by any broad, collective, or national repentance and apology (apologies were not

42. Cf. Geoffrey Barraclough, ch.vi in An Introduction to Contemporary History (Harmondsworth: Penguin Books, 1967).

43. Zweig, German Reparations, 4. 
forthcoming until some thirty years later). To take postwar German-Jewish relations as a model of political forgiveness or as a model for future conflict resolution is to misunderstand what actually occurred and to foster exaggerated hopes for social reconciliation elsewhere.

Nor is the case of South Africa as encouraging as it sometimes appears. Although Tutu repeatedly states that the Truth and Reconciliation Commission and the willingness of many to forgive and to reconcile provided means to avoid civil war and other forms of retribution in South Africa, the Commission was in fact as much the effect as the cause of a relatively peaceful transition to a new social order. The processes of negotiation for a new constitution and for reconciliation in South Africa began with the concern of the (white) government to maintain its power and meet large economic challenges. Plans for a truth-andreconciliation commission took shape only after Nelson Mandela had been set free and elected President.

In other parts of Africa-for example Mozambique-the conscious decision to set aside the past for present practical purposes, rather than to engage in public procedures of repentance and forgiveness, resembled the German-Jewish case. In general, the success of truth-and-reconciliation commissions in containing violence appears to have been mixed. ${ }^{44}$ These examples call into question the large claims about progress in international morality and the role of forgiveness in that process.

I have tried, through a detailed description of the German-Jewish case, to show that in general the notion of forgiveness was neither helpful nor necessary for political and social reconstruction. I therefore differ not only from the Christian perspective articulated by Tutu, but from the secularized view found in the work of Arendt. Arendt deemed forgiveness essential not only to political life but life in general; without it, no one would be able to act at all. ${ }^{45}$ She reasons that without forgiveness we would be paralyzed by our awareness of the mistakes of the past and by our fear of vengeance by the victims. "Forgiveness is the opposite of vengeance, which acts in the form of re-enacting an original trespassing." Forgiveness, as Arendt conceives it, is a secularized version of Jesus' teachings ("The fact that he made this discovery in a religious context. . is no reason to take it any less seriously. .."). It is a spontaneous movement of love toward the offender, which serves to "undo the past," and is the remedy for the "irreversibility of action." The only alternative, on her view, is punishment.

But we have seen that this is not the case. Neither forgiveness, nor vengeance, nor punishment was a central part of postwar Jewish-German reconstruction. What proved important was a willingness on the part of the leadership and

44. Cf. Hayner, Unspeakable Truths.

45. Hannah Arendt, The Human Condition (Chicago: The University of Chicago Press, 1958), 236-43. 
representatives of both "parties" to subordinate extremely painful memories to the perceived economic and political requirements of emerging democracies (West Germany and Israel). Regardless of whatever else was going on in the hearts and minds of the individual members of the German and Jewish populations with respect to forgiveness, governmental and other leaders took concrete measures that would begin to rectify at least part of the immeasurable injustices that had occurred, and that would advance the efforts of both nations to recover from the recent past. The two nations developed a limited yet ongoing relationship, without full reconciliation in the sense of going forward as though nothing had happened.

I recommend that the largely religious idea and vocabulary of forgiveness and reconciliation be removed from political activity. This does not imply, however, that all morality should be removed from politics. There are numerous moral values which do not necessarily involve religious concepts and traditions: keeping one's word; truth-seeking; peace-seeking; solidarity; and so on.

One implication that does follow from the German-Jewish case is that material reparations can and should be attempted. How this plays out in other specific cases, however, is an enormous problem. ${ }^{46}$ It is difficult to know where to begin when assessing economic losses incurred during mass atrocity or human-rights violations. Moreover, sometimes it may be difficult to begin rectification through material compensation without jeopardizing current needs for a minimally decent society.

Ultimately, what I am suggesting is that though material restitution may be a precondition for even minimal reconciliation and though efforts at political and social reconstruction can be attempted in various ways, repentance, forgiveness, and reconciliation are not essential components of reconstruction. They should be removed from political life, not introduced or re-introduced into it.

Capacities for repentance and forgiveness vary from one person to another (and perhaps one society to another). Although mourning, self-criticism, and remembrance may take on public forms, it is preferable that they take place between small groups and individuals without having to conform to the expectations, prerogatives, or constraints of the state. Through a well-known reversal of fortune, religious knowledges have become (secularist fears of fundamentalism notwithstanding) subjugated knowledges, to use Foucault's phrase. Nonetheless, in matters of forgiveness and memory, they are less likely to become too abstract and too lacking in cultural specificity than their secularpolitical counterparts.

46. In addition to the literature cited in note 1, the following are conceptually helpful: Thomas McCarthy, "Vergangenheitsbewaltigung in the USA: On the Politics of the Memory of Slavery," Political Theory 30 (2002): 623-48; Jeremy Waldron, "Superseding Historical Injustice," Ethics 103 (October 1992): $4-28$. 


\section{Is “Bracketing” Memory a Form of Injustice?}

The negotiations over restitution among Germany, Israel, and the world Jewish community were not reconciliation in any religious or philosophical sense. Nor did they involve an understanding or recognition of the identity of the other and its needs. Explorations of identity and the past imbrication of cultures (the German-Jewish symbiosis) came much later. What took place was the mutual setting aside of memory for the purposes of economic and political security.

Bracketing memory and separating religious notions of repentance and forgiveness from political life may be important for reconstruction, as opposed to reconciliation. They do not, however, obviate the question of whether memory is part of what we owe each other as human beings and as citizens. If self-esteem is a primary social good, and if recognition of one's historical narratives, memories, and cultural traditions are vital to self-esteem, then it would seem that there is a responsibility, on the part of citizens in a democracy, to see that every individual or group has the means to acquire and nurture such self-esteem. There is, in other words, an ongoing responsibility, beyond the generation of victims and perpetrators, to ensure the continuation of self-esteem based on different memories, narratives, identities, religious rituals, and so on. This is quite different from pursuing a "shared" past.

In an essay on "Injustice and Collective Memory," the political theorist Sheldon Wolin has suggested that forgetfulness or deliberate suppression of memory-or what I have called the bracketing of memory for security purposes-is a form of injustice. He deplores the "social amnesia" which allowed the United States to celebrate its bicentennial while apparently ignoring the historical wrongs done to Native Americans and many other groups. Wolin regards Hobbes as the main architect of this type of social amnesia:

Each of the three great contractualists insisted upon equal conditions of entry for all parties of contract; each was offered the same guarantees; each was subject to the same legal rules: Hobbes was the one writer who insisted not only on a contract on equal terms, but they also had to agree to forget some matters. . . . But what Hobbes was suppressing was not memory of personal grievances but recollections. . .of historical and collective actions, actions of kings, parliaments, judges, armies, civil war. A necessary condition of social amnesia was that men dehistoricize themselves. . . . The trade-off is equality for remembrance. ${ }^{47}$

47. Sheldon Wolin, "Injustice and Collective Memory," in his The Presence of the Past: Essays on the State and the Constitution (Baltimore: The Johns Hopkins University Press, 1989), 37-38. 
In the arena of international relations-as opposed to national politicsindividual states remain sovereign. But they are not equal, and international law provides unreliable guarantees. In such circumstances, it would be too much to say that equality is the trade-off for remembrance. Rather, as the German-Jewish case shows, it is security and participation in the world system of political economy that is the trade-off for remembrance. It was Israel's need to enter into the dynamics and conditions of "pure power," as Wolin would put it, which led it to enter into relations with Germany, despite the Holocaust.

Wolin makes a mistake in linking the suppression of memory with injustice. The bracketing of memory by victims or by their representatives and descendants for the vital purpose of security can be distinguished from the suppression of memory by perpetrators, by the state, or by society for the purposes of repression and control of minorities. Bracketing should also be distinguished from sheer ignorance or indifference. Moreover, the bracketing of memory does not preclude private remembrance of a regular or ritualized nature. It may not even involve, as Avishai Margalit has put it, a letting-go of resentment, in the sense of not reliving a certain emotion every time a certain memory is evoked. ${ }^{48}$ But bracketing does involve an ability to control that resentment and related emotions so as to enable the priority of common security or welfare to be realized.

The idea of bracketing memory for politico-economic purposes may suggest to some readers that people will be left with low levels of self-esteem or cultural identity. I see this problem at a public level as one of the costs of engaging in a constitutional democratic order, in which the value or principle of well-being for all takes precedence over the perfection of identity and its recognition. This does not mean, however, that individuals and groups may not strive to enhance their own modes of memory and to arrive at an enriched recognition of the identity of others. Nor does it mean that states can entirely ignore inequalities of opportunity for individual or group self-esteem and recognition. Debates on the obligation to remedy the effects of past crimes or discrimination, efforts to rectify past injustices, should take place. And these debates sometimes fall to subsequent generations rather than to victims and perpetrators themselves.

Those who disclaim any responsibility to do this (because they weren't there when the wrong was done, or had no direct or even indirect guilt or responsibility) are not only making a claim about temporal limitations on responsibility to rectify injustices. They are also embracing an underlying methodological individualism. They are resisting any notion of shared social responsibility, which

48. Avishai Margalit, The Ethics of Memory (Cambridge: Harvard University Press, 2002). A view of social reconciliation which is somewhat similar to mine may be found in Charles L. Griswold, Forgiveness: A Philosophical Exploration (Cambridge: Cambridge University Press, 2007), especially $192 \mathrm{ff}$. Griswold distinguishes between political apology and forgiveness. The former can facilitate a minimal level of cooperation, the latter involves "deep reunion, love and harmony." 
may be thought to arise from the political project of constructing democracy. How such a notion of shared responsibility to rectify injustices might be defended is beyond the scope of this paper. ${ }^{49}$ I will only say that I subscribe to the view that rectifying injustice is indeed part of what we owe to each other in terms of primary social goods.

I have argued that the principal proponents of reconciliation view world history as a moral-philosophical narrative ultimately founded upon Christian-Hegelian ideas. They envision an ideal end-state in which, in Hegel's phrase, "all griefs are healed," judgments are discarded as obstacles, and no scars are left behind. This is an ideal for metaphysical selves and of a metaphysical form of solidarity. This is not an ideal for real people, who are capable of suffering indelible wounds and who have only a limited capacity for repentance and forgiveness.

What would be preferable, in my view, would be to encourage and to speak only of practical goals in reconstruction. Moral judgments and cultural identities are neither abandoned nor "sublated" into some imaginary universal state or spirit, but remain constrained by the requirements of common if not communal life and peace. This is an approach which acknowledges the right of all individuals and groups to preserve their memories of injustice while participating in the ongoing construction of a secure, fair, and liberal society or international order.

To say that there has been some movement toward these aims since the end of World War II is not to believe one has discerned the emergence of either idealized reconciliation processes or a rapidly developing moral world community. I close with an observation from Immanuel Kant who, though often read as an exponent of an ideal of international peace and justice, may have been closer to the position I have been advancing. He wrote in the renowned essay Perpetual Peace:

On the other hand, nature also unites nations which the concept of cosmopolitan right would not have protected from violence and war, and does so by means of their mutual self-interest. For the spirit of commerce sooner or later takes hold of every people, and it cannot exist side by side with war. And of all the powers (or means) at the disposal of the power of the state, financial power can probably be relied upon most. Thus states find themselves compelled to promote the noble cause of peace, though not exactly from motives of morality. ${ }^{50}$

49. In addition to the topic of material reparations, discussed by McCarthy and Waldron (note 46), the topic of recognition and reconciliation of identities in a multicultural society is discussed by Amy Gutmann and Dennis Thompson, "The Moral Foundations of Truth Commissions," in Truth v. Justice: The Morality of Truth Commissions, ed. Robert I. Rotberg and Dennis Thompson (Princeton: Princeton University Press, 2000).

50. Kant: Political Writings, ed. Hans Reiss, trans. H.B. Nisbet. 2nd ed. (Cambridge, UK: Cambridge University Press, 1991), 114, emphasis in the original. 
Jean Cahan received her B.A. and M.A. in European History from McGill University in Montreal and her Ph.D. in Philosophy from The Johns Hopkins University in Baltimore. She is currently at the University of Nebraska-Lincoln. Her research interests include the philosophy of Spinoza, Marxism, and modern Jewish thought. She can be reached at jcahan1@unl.edu. 